Evolution education: treating evolution as a sensitive rather than a controversial issue

Michael J Reiss

UCL Institute of Education, 20 Bedford Way, London WC1H 0AL, UK

m.reiss@ucl.ac.uk

ORCID: 0000-0003-1207-4229

Reiss, M. J. (2019) Evolution education: treating evolution as a sensitive rather than a controversial issue. Ethics and Education. DOI: 10.1080/17449642.2019.1617391 


\title{
Evolution education: treating evolution as a sensitive rather than a controversial issue
}

\begin{abstract}
Evolution is often seen as a site of contestation within the school curriculum. The topic of evolution is therefore often considered to be 'controversial'. I first examine what is meant by 'controversial' and conclude that while, in an everyday sense, the topic of evolution can indeed be considered to be controversial, this term can mislead. A more fruitful way forward may be to regard the topic of evolution as 'sensitive'. I examine reasons why evolution might be considered sensitive - noting that for a not inconsiderable number of people it is so because of perceived conflict with religious views and also because it may be existentially disturbing for some. Rather little attention has been paid in the philosophy of education literature as to how we might deal with sensitive issues. I therefore look at what we mean by describing an issue as sensitive and at how teachers might deal in the classroom with such issues, specifically evolution.
\end{abstract}

Keywords: Evolution education; controversial issues; sensitive issues; creationism; intelligent design

Word count: 7227 (including Abstract and References) 


\section{Evolution education: treating evolution as a sensitive rather than a controversial issue}

\section{The importance of evolution education for schools}

Evolution education raises issues for education that are of conceptual interest and have practical significance. These issues include the aims of schooling, how we arrive at knowledge that is reliable, and how schools should deal with issues that raise difficulties on the grounds of their controversy or sensitivity. It is clear that evolution education is therefore of considerably more interest to philosophers of education than most other topics within the school science curriculum (think covalent bonding, Newton's equations of motion and the alimentary canal). There are a number of reasons for this but chief among them are creationism and intelligent design.

Creationism exists in a number of different forms but, depending on the country, from as few as $5 \%$ to over $50 \%$ of adults reject the theory of evolution and can be described as creationists (Deniz and Borgerding 2018). The most common reason for rejecting the theory of evolution is believing that the Earth came into existence as described by a literal (sometimes described as fundamentalist) reading of the early parts of the Bible, the Qu'ran or other scriptures and that the most that evolution has done is to change species into fairly closely related species (Miller, Scott, and Okamoto 2006; Reiss 2011). For a creationist it is possible, for instance, that the various different species of deer had a common ancestor but this is not the case for the various species of deer, hedgehogs and dogs - still less for monkeys and humans, for mammals and amphibians or for the blue whale, tapeworms and the banana.

Related to creationism is the less widely held and more recent theory of intelligent design. Many of those who argue for intelligent design have been involved in the creationism movement; indeed, the US courts have concluded that the country's First Amendment separation of religion and the State means that intelligent design cannot permissibly be taught in public schools (Moore 2007). However, those who advocate the theory of intelligent design can claim that it is a theory that simply critiques the tenets of evolutionary biology and is independent of matters to do with religious faith. Those who promote intelligent design generally come from a conservative, faithbased position. Nevertheless, in their arguments, many of them make no reference to scriptures 
or a deity but argue that the exceptional intricacy and goodness of fit of what we see in the natural world, especially at an intracellular scale, constitutes powerful evidence for the existence of an intelligence (hence, 'intelligent design' - without the nature of that intelligence being specified) behind this (e.g. Behe 1996; Dembski 1998; Johnson 1999). Standard scientific explanations for the diversity of life (mainly, the theory of natural selection) are held to be insufficient.

Until a decade or two ago, little attention had been paid in the biology classroom or the philosophy of education literature to creationism and almost none to intelligent design. However, creationism and intelligent design seem to be on the increase, and there are certainly more countries in which schools are becoming battlegrounds for the issue. While the USA has had several decades of legal contestations about the place of creationism and (more recently) intelligent design in schools (Moore 2007), school-based conflicts over these issues are becoming more frequent in a number of other countries, across the globe (Graebsch and Schiermeier 2006; Blancke, Hjermitslev, and Kjærgaard 2014; Deniz and Borgerding 2018). For example, there was consternation in UK science education circles when, in December 2009, many secondary school and higher education libraries received a complimentary copy of the book by Stephen Meyer et al. (2009) titled Explore Evolution, which advocated intelligent design.

Such events have led to a corresponding growth in the educational literature examining creationism and/or intelligent design (e.g. Jones and Reiss 2007; Williams 2008; Laats and Siegel 2016; Reiss 2018).

There are other sites, aside from the school classroom, where creationism and intelligent might be addressed. In particular, there is the beginning of a literature on the way that museums present the issue of evolution (Bennett 2004; Scott 2007; Trollinger and Trollinger 2016; Reiss 2017), while many of us also learn about evolution, creationism and intelligent design through radio and TV programmes, by reading popular science books and from websites. However, there is a particular need to address the issue of whether, and if so how, schools might address the issues of 
creationism and intelligent design, particularly for the age range of students for whom education is mandatory, where evolution in many countries is a core part of the biology curriculum.

\section{Is the theory of evolution a controversial issue?}

It may appear surprising to ask if the theory of evolution is a controversial issue for two rather different reasons. First of all, how can a well-established scientific theory be considered controversial? After all, the theory of evolution is not controversial in the sense that the genetic modification of organisms is - where the controversy is not over the basic science but over whether we should or should not genetically modify organisms. In terms of science, rather than ethics, the consequences of anthropogenic climate change might be deemed controversial, at least in part on the grounds that there is much that we genuinely don't know about these consequences, but this is not what is meant by the theory of evolution being controversial. Although, as with any science, there is uncertainty at the edges of the science, the core ideas of evolution have been well-established within the science for many decades. Among the overwhelming majority of scientists, the theory of evolution is nowadays no more scientifically controversial than is the Periodic Table, quantum dynamics and plate tectonics.

The second reasons why it may appear surprising to ask if the theory of evolution is a controversial issue is because of the furore that regularly surrounds it in many countries in the courts, in the media and in schools - surely it is controversial! The question is a useful one because there is a considerable literature on how controversial issues might be addressed in education in general (e.g. Cowan and Maitles 2012) and for evolution in particular (e.g. Reiss 2018). Much of the academic literature in education on controversial issues relies on the work of Robert Dearden (1981/1984), though, intriguingly, some writing on the issue, e.g. the book Teaching Controversial Issues in the Classroom: Key Issues and Debates (Cowan and Maitles 2012) manages to avoid defining, let alone discussing, what is meant by a 'controversial issue'.

Dearden pointed out that "what is "controversial" may itself be a matter of controversy' (Dearden $1981 / 1984,85)$. He then went on to propose an epistemic criterion in which, as is well known, 'a 
matter is controversial if contrary views can be held on it without those views being contrary to reason' (86). He pointed out that several possible kinds of controversial issue may be distinguished: 'cases where we simply have insufficient evidence to settle the matter, though in principle there is no reason why it should not be settled as more or better evidence becomes available ... where consideration-making criteria are agreed but the weight to be given them is not ... where there is no agreement even on the criteria as to what will count' (86) and, finally, 'where not just individual criteria but whole frameworks of understanding are different' (87). For science education, this four-fold categorisation has been valuably extended by Levinson (2006).

At the same time, Dearden's epistemic criterion of the controversial is not the only one. Indeed, other definitions are often presented (e.g. Wellington 1986; Claire and Holden 2007; Hess 2009). The opening chapter of The Challenge of Teaching Controversial Issues states:

In general terms a controversial issue is one in which

- the subject/area is of topical interest

- there are conflicting values and opinions

- there are conflicting priorities and material interests

- emotions may become strongly aroused

- the subject/area is complex.

(Claire and Holden 2007, 5-6)

This is a much more diffuse definition that that provided by Dearden.

There is a large literature in education on controversial issues (e.g. Stradling 1984; Bridges 1986; McLaughlin 2003; Hand 2008). Michael Hand (2008) has defended and developed Dearden's epistemic account, arguing that 'What distinguishes teaching-as-settled from teaching-ascontroversial (or directive from nondirective teaching) is not a pedagogical method or style, but the willingness of the teacher to endorse one view on a matter as the right one' (Hand, 2008, 213). Hand is explicit that "The English word "controversial" means simply "disputed", and the existence of dispute is an unpromising criterion for what should be taught nondirectively' (214). He then criticises curriculum materials and guides that take too broad a view of controversy. In 
particular, he points out that topics such as bullying and racism are frequently described as controversial, yet this hardly fits with standard advice typically given in such materials and guides that teachers should teach controversial issues in a balanced manner, giving equal weight to opposing views.

However, I am not entirely persuaded by Hand's arguments (Reiss 2011). Hand relies on the assertion that 'that the central aim of education is to equip students with a capacity for, and inclination to, rational thought and action' (218). This seems to me a narrow view. Considerations of space preclude me from discussing here all the arguments as to the aims of education (cf. Marples 1999; White 2011; Kristjánsson 2015) but Hand privileges rationality. Along with John White and others, I prefer an emphasis on human flourishing (e.g. Reiss and White 2013). Furthermore, unless one defines 'controversy' at a particular time and place and for a particular audience, or to hope for a view from nowhere that will provide a way of objectively deciding disagreements to do with whether alternative positions on issues can rationally be held, it seems evident that attempts simply to divide issues into 'controversial' and 'non-controversial' categories are unlikely often to succeed. There are degrees of controversy; as Hand and many others acknowledge, what is controversial for one group of people may not be controversial for another.

Focusing now on evolution, the scientific understanding of biodiversity is not complete but the overall narrative has been consistent for decades. By 3.5 billion years ago, probably a few hundred million years earlier, life had evolved on Earth. By the time of the earliest fossils, which date from about this time or soon after, life was unicellular and, at least superficially, looked like some of today's bacteria. Between then and now, natural selection, along with other mechanisms (e.g. genetic drift), led to the very large number of species, including our own, that are presently in existence.

This scientific understanding is considered uncontentious among the great majority of scientists. At the same time, there is much that remains unknown about evolution. How did the earliest selfreplicating molecules come into existence? What caused the membranes that today surround all cells to exist? How crucial were the earliest physical conditions in which life arose - 
temperature, the occurrence of water, $\mathrm{pH}$ and so forth? Despite such uncertainties, the scientific presumption is that these questions will either be answered, whether sooner or later, by science or remain unknown. Although some scientists (sometimes grudgingly) admit that science cannot disprove supernatural explanations, scientists do not make use of such explanations in their work - the tiny handful of exceptions, not infrequently when such scientists are writing outside their specialist field, only attest to the strength of the general rule.

There is only one mainstream scientific account of biodiversity; however, there are a considerable number of religious ones. Many religious believers and the institutions to which they belong (e.g. the Roman Catholic Church) are perfectly comfortable with the scientific understanding, either on its own or accompanied by a presumption that evolution in some sense takes place within God's overall plan, whether or not God is presumed to have intervened or acted providentially at certain key points (e.g. the origin of life or of humans). But many other religious believers hold a more creationist perspective or that of intelligent design (Reiss, 2008a).

Most of the writing on creationism and intelligent design puts them in direct conflict with evolutionary theory. Evolution is consistently presented in creationist books and articles as illogical (e.g. natural selection cannot - the second law of thermodynamics - create the order that we see in living organisms out of the less ordered constituents of which such organisms are composed; mutations are always harmful and so cannot lead to improvements over time), contradicted by scientific evidence (e.g. the fossil record shows human footprints alongside animals, such as dinosaurs, supposed by evolutionists to be long extinct before humans had evolved; the fossil record does not provide evidence for transitional forms, such as would be expected if, for example, bats had arisen from non-flying mammals), the product of nonscientific reasoning (e.g. the origin of life would require life to arise from inorganic matter whereas spontaneous generation has long been rejected by science; radioactive dating makes unwarranted assumptions about the constancy of natural processes over aeons of time whereas we increasingly know of natural processes that affect rates of radioactive decay), the product of atheists who ridicule the word of God, and a cause of a whole range of social evils (eugenics, Marxism, Nazism, racism, etc) - e.g. Baker (2003), Parker (2006) and countless articles in the writings of creationist organisations or those that argue for intelligent design. 
Creationism and intelligent design have received comparable criticism from those who accept the theory of evolution. The philosopher of science Philip Kitcher argued that 'in attacking the methods of evolutionary biology, Creationists are actually criticizing methods that are used throughout science' (Kitcher 1983, 4-5). Kitcher concluded that flat-Earth theory, the chemistry of the four elements, and mediaeval astrology 'have just as much claim to rival current scientific views as Creationism does to challenge evolutionary biology’ (5).

Many scientists have defended evolutionary biology against creationism and intelligent design (e.g. Selkirk and Burrows 1987; Good et al. 1992; Interacademy Panel on International Issues 2006). The main points typically made are that evolutionary biology is good science (e.g. not all science consists of controlled experiments where the results can be collected within a short period of time - cf. cosmology and some ecology), that creationism (including so-called 'scientific creationism') isn't a science in that its ultimate authority comes not from observations of the natural world or experimentation but from a particular reading of scriptures, and that an acceptance of evolution is fully compatible with a religious faith (cf. the International Society for Science and Religion www.issr.org.uk).

\section{Is the theory of evolution a sensitive issue?}

I propose that an alternative way forward for evolution education may not be to argue about whether or not the theory of evolution is a controversial issue but to accept that, for at least some students, it is clearly a sensitive one. The word 'sensitive' has several cognate meanings; it derives from the mediaeval Latin sensitivus, which itself comes from the classical Latin sentire, meaning 'to feel'. We can talk, for example, about our eyes being sensitive to light in a way that has no evaluative connotations, simply being a description of empirical reality. However, the meaning that I am concerned with is specifically to do with the effects on a person's emotional feelings rather than on their various receptors (eyes, ears, proprioceptors and so on). 
A word about the form of my argument. Whereas one can, in principle, argue about whether or not evolution satisfies the epistemic criterion of controversy without considering the students who are to be taught about evolution, in arguing that evolution might profitably be taught as a sensitive issue my focus is entirely on the students who are to be taught and on how some of them feel about evolution. I have in mind students of school age. When, for example, considering how to teach evolution to higher education students who have chosen to study biology, there may be less need, at least in some countries, to treat evolution as a sensitive issue - though I have myself taught biology undergraduates who were creationists and it has long been known that among, for instance, medical students there are many creationists even a country like Scotland (Downie and Barron, 2000) which, by international standards, has relatively low levels of religious observance.

Furthermore, I do not claim that my argument is watertight (as in formal logic). It is more a combination of a number of sub-arguments, each of which contributes, I maintain, to the overall weight of argument. Darwin himself used this approach in writing his one long argument in $O n$ The Origin of Species - and was criticised by some for it at the time. In fact, though, this is how knowledge often advances in those sciences, like evolution and cosmology, where experiments are either not possible or are rarer than in the textbook versions of 'the scientific method' that are generally taught in school.

There are a number of advantages in considering the theory of evolution as a sensitive issue. For a start, as is clear from the above section 'Is the theory of evolution a controversial issue?', whatever the understandings of philosophers of education about the meaning of the term 'controversial', the term is evidently often used by educators (e.g. Claire and Holden 2007; Cowan and Maitles 2012 and chapters therein) in its everyday sense - a sense which, I argue, is close to or even the same as 'sensitive'. Then there is the advantage that as humans most of us are quite good at knowing how to behave when dealing with someone for whom an issue is sensitive (think a bereaved friend or colleague, or someone worried about their sexual identity or whether their country should go to war): we are careful with our language, more hesitant in our speech, more alert to the possibility that the other person may be upset by something we say or some feature of our non-verbal communication. This is not the same as dealing with an issue that 
is controversial. With certain exceptions, most humans are better at dealing with issues that have associated emotional impacts than they are at dealing with rational arguments (a truth extensively explored by psychologists in recent years - e.g. Kahneman, 2011).

But, it might be objected, the topic of evolution is sensitive only for some students. I agree - but this is in the nature of sensitive issues (Lee 1993). The extent to which an issue is sensitive tells us something about the person as well as the issue. One person may not find the issue of sexual orientation to be sensitive - I include myself in this grouping - another may; the same point applies to other sensitive issues. Indeed, this very context-specificity of sensitive issues means that some sort of classification, for all times and in all places, of topics into those that are sensitive and those that are not may not be helpful. I am pretty sure that the topic of evolution was a sensitive one for few if any of my school biology students when I started teaching in Cambridge in 1983. However, as the years went by, this became less the case and certainly now, teaching postgraduate students in 2018, most of whom are going to be school teachers in and around London, a far more multicultural city than Cambridge was some 35 years earlier, the issue is sufficiently sensitive and pertinent that I am asked each year by those who organise our course for pre-service secondary science teachers to teach how evolution might be taught in schools, as part of a session on science and religion.

There is quite an extensive literature associated with the teaching of sensitive issues, though not all of it is directly applicable to the classroom. Countering the argument that such teaching may not be wanted, Conway (2004) found strong support among school students in England and Northern Ireland for the notion that sensitive issues should be addressed in history lessons. She also found that when a topic was considered to be emotional, teachers tended to rely more on the use of documents rather than on classroom discussion. Warren's (2006) article is titled 'What should and should not be said: Deliberating sensitive issues', which sounds promising but he adopts a very particular (and much narrower) definition for sensitive issues than the one I use here, stating that they 'necessarily and involuntarily reference inherited status inequalities of speakers as part of the content of speech in ways that destabilize deliberation' (163). 
In an article written from a feminist perspective, Durfee and Rosenberg (2009) discuss how college-level courses that focus on 'social problems' (e.g. domestic abuse, shootings on campus) can 'evoke a wide range of responses from students - including shock, disbelief, anger, tears, and/or depression - that can even compel some students to physically leave the classroom' (104). Durfee and Rosenberg discuss the value of paying careful attention to the course materials that are used (e.g. so that they do not objectify individual victims or marginalized groups), discussing ground rules for class discussions at the start of the course, helping students access local resources (i.e. sources of support and help) and listening attentively to the stories (often autobiographical) that students tell.

Lowe and Jones (2010) begin by helpfully pointing out that there is a much larger literature in education on how to research sensitive issues than how to teach them. Theirs is the first article in the special issue of a journal that they edited. The papers that follow go on to consider how teaching might be undertaken for such sensitive topics as HIV, sexual assault, partner violence, the use of sexually explicit materials in the classroom, 'race' and ethnicity, death studies, terrorism, among others. However, Lowe and Jones also point out that 'Almost any topic can become sensitive if emotional responses are raised, if there are competing explanations about events, if there are political differences about what should happen next or challenges about how issues could be resolved' (2).

Faced with such a daunting list of topics as that in Lowe and Jones (2010), it might be wondered whether evolution really is a sensitive issue. Although I am unaware of any systematic evidence that evolution be considered as a sensitive issue, Asghar, Wiles, and Alters (2007) found that about $22 \%$ of the pre-service teachers in their study viewed evolution education as a 'delicate', 'sensitive' and 'touchy' matter. Hildebrand, Kimberly, and Capps (2008) asked 'How can such problems be addressed in a way that is ethically sensitive and intellectually responsible?' (1033), but do not discuss the words 'sensitive' or 'sensitivity'. There are other articles that cite the need for teacher sensitivity when teaching about evolution but do not discuss in any detail what is meant by this (e.g. Dagher and BouJaoude 1997; Meadows, Doster, and Jackson 2000; Robbins and Roy 2007). 
To the fairly obvious point that evolution is sensitive for some students because, as a consequence of their religious beliefs, it is perceived strongly to clash with how they understand the world, another reason can be added, though the literature about this is much sparser.

Evolution may be sensitive for some learners because some of its key notions - that the universe may not have some pre-determined aim, that chance has play a major role in our being here, and so on - can cause existential anxieties (Tracy, Hart, and Martens 2011; Newall 2017). Faced with these, learners may feel safer consciously or unconsciously pushing evolutionary ideas to the back of their mind; they may therefore be resistant to them and teachers would do well to treat such students with sensitivity.

\section{Dealing with creationism and intelligent design in the secondary science classroom}

Few countries have produced explicit guidance as to how creationism or intelligent design might be dealt with in school science lessons. Indeed, the government production of such guidance raises issues about the extent to which it is appropriate (or even feasible in countries with significant geographical variation in relevant parameters, such as religious observance) for the state to propose or enforce a common view on such issues. It may often be wise to allow decisions to be made at more local levels, whether by school boards, parents, teachers or others.

One country that has produced such guidance is England. In the summer of 2007, after behindthe-scenes meetings and discussions, the then DCSF (Department of Children, Schools and Families) Guidance on Creationism and Intelligent Design received Ministerial approval and was officially published (DCSF 2007). The Guidance pointed out that the use of the word 'theory' in science (as in 'the theory of evolution') can mislead those not familiar with science as a subject discipline because it is different from the everyday meaning (when it is often used to mean little more than an idea). In science the word indicates that there is a substantial amount of appropriate supporting evidence, underpinned by principles and explanations accepted by the international scientific community and backed up by peer-reviewed publications. The Guidance goes on to state: 'Creationism and intelligent design are sometimes claimed to be scientific theories. This is not the case as they have no underpinning scientific principles, or explanations, and are not 
accepted by the science community as a whole' (DCSF 2007). The Guidance then goes on to say:

Creationism and intelligent design are not part of the science National Curriculum programmes of study and should not be taught as science. However, there is a real difference between teaching ' $\mathrm{x}$ ' and teaching about ' $\mathrm{x}$ '. Any questions about creationism and intelligent design which arise in science lessons, for example as a result of media coverage, could provide the opportunity to explain or explore why they are not considered to be scientific theories and, in the right context, why evolution is considered to be a scientific theory.

(DCSF 2007)

This seems to me a key point (OK, I admit, I wrote it) and one that is independent of country, whether or not a country permits the teaching of religion in state schools (as in the UK) or does not (as in France and the USA). Many scientists, and some science educators, fear that consideration of creationism or intelligent design in a science classroom legitimises them. For example, the generally excellent book Science, Evolution, and Creationism published by the US National Academy of Sciences and Institute of Medicine asserts 'The ideas offered by intelligent design creationists are not the products of scientific reasoning. Discussing these ideas in science classes would not be appropriate given their lack of scientific support' (National Academy of Sciences and Institute of Medicine 2008, 52).

As I have argued (Reiss, 2008b), I agree with the first sentence of this quotation but disagree with the second. Just because something lacks scientific support is not a sufficient reason to omit it from a science lesson. Indeed, to maintain that something that lacks scientific support should not be taught in school science lessons is to fail to understand effective ways of teaching. One does not teach well by simply ignoring non-standard views. Indeed, by ignoring such views, one may be more likely to ensure that they survive. A different objection is provided by Nancy Brickhouse and Will Letts (1998) who argue that one of the central problems in science education is that science is often taught 'dogmatically'. With particular reference to creationism they write: 
Should student beliefs about creationism be addressed in the science curriculum? Is the dictum stated in the California's Science Frameworks (California Department of Education, 1990) that any student who brings up the matter of creationism is to be referred to a family member of member of the clergy a reasonable policy? We think not. Although we do not believe that what people call 'creationist science' is good science (nor do scientists), to place a gag order on teachers about the subject entirely seems counterproductive. Particularly in parts of the country where there are significant numbers of conservative religious people, ignoring students' views about creationism because they do not quality as good science is insensitive at best.

(Brickhouse and Letts 1998, 227)

More recently, Thomas Nagel (2008) has argued that so-called scientific reasons for excluding intelligent design (ID) from science lessons do not stand up to rigorous scrutiny (cf. Koperski 2008). With reference to the USA he concludes:

I understand the attitude that ID is just the latest manifestation of the fundamentalist threat, and that you have to stand and fight them here or you will end up having to fight for the right to teach evolution at all. However, I believe that both intellectually and constitutionally the line does not have to be drawn at this point, and that a noncommittal discussion of some of the issues would be preferable.

(Nagel 2008, 205)

\section{Discussion}

Whatever the subject matter and age range of a class, and the country in which a teacher is teaching, there is much to be said for a teacher bearing in mind that for some students, evolution is likely to be a sensitive issue. As discussed above, less has been written in the philosophy of education literature about sensitive issues than about controversial ones. Death, sexuality, drugs policy, genocide and animal experimentation are examples of issues that are sensitive for many 
students; many teachers, in a range of secondary / high school subjects as well as primary / elementary teachers across the curriculum, are used to dealing respectfully, considerately and caringly with students when sensitive issues arise. Teachers should keep in mind that they may not always be aware of specific students for whom evolution is a sensitive issue, just as they may not be aware of students for whom other topics are sensitive ones.

An advantage of shifting the discourse from controversy to sensitivity is that one shifts the focus from epistemology to pedagogy. The reason this is advantageous is that the large majority of teachers have far more understanding of pedagogy than they do of epistemology. While in some countries, teachers enter teaching with some knowledge of philosophy, including epistemology, or acquire it during their teaching careers, there are many countries where this is not the case. On the other hand, pedagogy is, hardly surprisingly, a core feature of courses in initial teacher education and continuing professional development.

Furthermore, one can be sensitive towards someone in respect of an issue without implying that one shares the same perspective (or worldview) as the person to whom one is being respectful and considerate. Different notions of respect are discussed by Rosenblith and Bindewald (2014) who 'make a case for an approach to civic education in the public schools that is rooted in engagement' (596). Explicitly accepting the teaching of evolution as controversial is difficult for many science teachers as the distinction between this and evolution as controversial is a fine one and many science teachers are likely to see it as selling out to creationists (cf. Hermann 2008).

Of course, my suggestion that teaching in this field be considered akin to the teaching of traditional sensitive issues does not absolve teachers and relevant others such as curriculum designers and textbook authors (Williams 2008), whatever their specialisms, from having as good a knowledge of evolution as they can. It is more about how evolution is presented.

Pre-service teachers can be helped to teach and manage sensitive issues (Lynagh, Gilligan, and Handley 2010). In a school science lesson when teaching evolution there is much to be said for allowing students to raise any doubts about evolution that they have - whatever the origins of these doubts - and doing one's best in such circumstances to have a genuine scientific discussion 
about the issues raised. The word 'genuine' does not mean that creationism or intelligent design deserve equal time with evolution (a concern of some biology educators if discussion of creationism and/or intelligent design is to be allowed in science lessons), nor does it mean that a science teacher should present creationism or intelligent design as valid scientific alternatives to the theory of evolution. It is perfectly appropriate for a science teacher to critique arguments, or encourage students to critique arguments, for creationism or intelligent design that purport to be scientific. In certain classes, depending on the comfort of the teacher in dealing with such issues and the make up of the student body, it can be appropriate to deal with these issues. If questions about the validity of evolution or issues about creationism and intelligent design arise during science lessons, a teacher may be able to use them to illustrate a number of aspects of the nature of science, including how scientific knowledge is built up over time while always being open to the possibility of refutation and change.

That having been said, teaching about evolution when considerations of creationism or intelligent design are pertinent is often challenging. Some students get very heated; others remain silent even if they disagree profoundly with what is said by others (fellow students or the teacher). It behoves science educators seriously and respectfully to bear in mind the concerns of students who do not accept the theory of evolution while still introducing them to it. There is much to be said for aiming to get students to understand rather than necessarily to believe or accept the theory of evolution (Smith and Siegel 2004; Reiss 2008b). While it is unlikely that even respectful teaching that considers the theory to evolution to be a sensitive issue will help students who have a conflict between science and their religious beliefs to resolve the conflict there and then, good science teaching can help students to manage it - and to learn more science (cf. Winslow, Staver, and Scharmann 2010; Long 2011).

\section{Acknowledgements}

A version of this paper was given at the International Network of Philosophy of Education (INPE) Conference at Haifa, Israel in 2018. I am also very grateful to valuable feedback from two reviewers. 


\section{Declaration of interest}

None

\section{References}

Asghar, A., J. R. Wiles, and B. Alters. 2007. “Canadian pre-service elementary teachers' conceptions of biological evolution and evolution education." McGill Journal of Education 42 (2): 189-210.

Baker, S. 2003. Bone of Contention: Is Evolution True? $3^{\text {rd }}$ ed. Rugby: Biblical Creation Society.

Behe, M. J. 1996. Darwin's Black Box: The Biochemical Challenge to Evolution. New York: Free Press.

Bennett, T. 2004. Pasts Beyond Memory: Evolution, Museums, Colonialism. London: Routledge.

Blancke, S., H. H. Hjermitslev, and P. C. Kjærgaard, eds. 2014. Creationism in Europe. Baltimore: John Hopkins University Press.

Brickhouse, N. W., and W. J. Letts IV. 1998. "The problem of dogmatism in science education." In Curriculum, Religion, and Public Education: Conversations for an Enlarging Public Square, edited by J. T. Sears and J. C. Carper, 221-230. New York: Teachers College, Columbia University.

Bridges, D. 1986. "Dealing with controversy in the curriculum: a philosophical perspective.” In Controversial Issues in the Curriculum, edited by J. J. Wellington, 19-38. Oxford: Basil Blackwell.

California Department of Education. 1990. Science Framework for California Public Schools. Sacramento: California Department of Education.

Claire, H., and C. Holden, eds. 2007. The Challenge of Teaching Controversial Issues. Stoke-onTrent: Trentham.

Conway, M. 2004. "Identifying the past: An exploration of teaching and learning sensitive issues in history at secondary school level." Educate, 4 (2). 
Cowan, P., and H. Maitles, eds. 2012. Teaching Controversial Issues in the Classroom: Key Issues and Debates. London: Continuum.

Dagher, Z. R., and S. BouJaoude. 1997. "Scientific views and religious views of college students: The case of biological evolution." Journal of Research in Science Teaching 34 (5): $429-445$.

DCSF. 2007. Guidance on Creationism and Intelligent Design. www.teachernet.gov.uk/docbank/index.cfm?id=11890.

Dearden, R. F. 1984. Theory and Practice in Education. London: Routledge \& Kegan Paul.

Dembski, W. A. 1998. The Design Inference: Eliminating Chance through Small Probabilities. Cambridge: Cambridge University Press.

Deniz, H., and L. A. Borgerding, eds. 2018. Evolution Education Around the Globe. Dordrecht: Springer.

Downie, J. R., and N. J. Barron. 2000. "Evolution and religion: Attitudes of Scottish first year biology and medical students to the teaching of evolutionary biology." Journal of Biological Education 34 (3): 139-146.

Durfee, A., and K. Rosenberg. 2009. "Teaching sensitive issues: Feminist pedagogy and the practice of advocacy-based counseling." Feminist Teacher 19 (2): 103-121.

Good, R. G., J. E. Trowbridge, S. S. Demastes, J. H. Wandersee, M. S. Hafner, and C. L. Cummins, eds. 1992. Proceedings of the 1992 Evolution Education Research Conference. Baton Rouge: Louisiana State University.

Graebsch, A., and Q. Schiermeier. 2006. "Anti-evolutionists raise their profile in Europe.” Nature 444: 406-407.

Hand, M. 2008. "What should we teach as controversial? A defense of the epistemic criterion." Educational Theory 58: 213-228.

Hermann, R. S. 2008. "Evolution as a controversial issue: a review of instructional approaches." Science \& Education 17: 1011-1032.

Hess, D. E. 2009. Controversy in the Classroom: The Democratic Power of Discussion. New York: Routledge.

Hildebrand, D., B. Kimberly, and J. Capps. 2008. “Addressing controversies in science education: A pragmatic approach to evolution education." Science \& Education 17: 10331052. 
Interacademy Panel on International Issues. 2006. IAP Statement on the Teaching of Evolution. http://www.interacademies.net/File.aspx?id=6150.

Johnson, P. E. 1999. "The wedge: breaking the modernist monopoly on science.” Touchstone 12 (4): $18-24$.

Jones, L., and M. J. Reiss, eds. 2007. Teaching about Scientific Origins: Taking Account of Creationism. New York: Peter Lang.

Kahneman, D. 2011. Thinking Fast and Slow. New York: Farrar, Straus and Giroux.

Kitcher, P. 1983. Abusing Science: The Case against Creationism. Milton Keynes: Open University Press.

Koperski, J. 2008. "Two bad ways to attack intelligent design and two good ones.” Zygon, 43: 433-449.

Kristjánsson K. 2015. Aristotelian Character Education. London: Routledge.

Laats, A., and H. Siegel. 2016. Teaching Evolution in a Creation Nation. Chicago: University of Chicago Press.

Lee, R. M. 1993. Doing Research on Sensitive Topics. London: Sage.

Levinson, R. 2006. "Towards a theoretical framework for teaching controversial socio-scientific issues.” International Journal of Science Education 28: 1201-1224.

Long, D. 2011. Evolution and Religion in American Education: An Ethnography. Dordrecht: Springer.

Lowe. P., and H. Jones. 2010. "Teaching and learning sensitive topics." Enhancing Learning in the Social Sciences 2 (3): 1-7.

Lynagh, M., C. Gilligan, and T. Handley. 2010. “Teaching about, and dealing with, sensitive issues in schools: How confident are pre-service teachers?" Asia-Pacific Journal of Health, Sport and Physical Education 1 (3-4): 5-11.

McLaughlin, T. 2003. “Teaching controversial issues in citizenship education.” In Education for Democratic Citizenship: Issues of Theory and Practice, edited by A. Lockyer, B. Crick and J. Annette, 149-160. Avebury: Aldershot.

Marples, R., ed. 1999. The Aims of Education. London: Routledge.

Meadows, L., E. Doster, and D. F. Jackson. 2000. "Managing the conflict between evolution \& religion." American Biology Teacher 62 (2): 102-107. 
Meyer, S. C., P. A. Nelson, J. Moneymaker, S. Minnich, and R. Seelke. 2009. Explore Evolution: The Arguments for and against Neo-Darwinism. Melbourne: Hill House.

Miller, J. D., E. C. Scott, and S. Okamoto. 2006. "Public acceptance of evolution." Science, 313 : 765-766.

Moore, R. 2007. “The history of the creationism/evolution controversy and likely future developments." In Teaching about Scientific Origins: Taking Account of Creationism, edited by L. Jones and M. Reiss, 11-29. New York: Peter Lang.

Nagel. T. 2008. "Public education and intelligent design.” Philosophy \& Public Affairs 36: 187205.

National Academy of Sciences and Institute of Medicine. 2008. Science, Evolution, and Creationism. Washington, DC: National Academies Press.

Newall, E. 2017. “Evolution, insight and truth?” School Science Review, 99 (367): 61-66.

Parker, G. E. 2006. Creation: Facts of Life-How Real Science Reveals the Hand of God. Los Angeles, CA: New Leaf Press.

Reiss, M. J. 2008a. "Should science educators deal with the science/religion issue?" Studies in Science Education 44: 157-186.

Reiss, M. J. 2008b. “Teaching evolution in a creationist environment: an approach based on worldviews, not misconceptions.” School Science Review 90 (331): 49-56.

Reiss, M. J. 2011. "How should creationism and intelligent design be dealt with in the classroom?" Journal of Philosophy of Education 45: 399-415.

Reiss, M. J. 2017. "Teaching the theory of evolution in informal settings to those who are uncomfortable with it." In: Preparing Informal Science Educators: Perspectives from Science Communication and Education, edited by P. G. Patrick, 495-507. Cham: Springer.

Reiss, M. J. 2018. “Creationism and Intelligent Design.” In: International Handbook of Philosophy of Education, edited by P. Smeyers, 1247-1259. Dordrecht: Springer.

Reiss, M. J., and J. White. 2013. An Aims-based Curriculum: The Significance of Human Flourishing for Schools. London: IOE Press.

Robbins, J. R., and R. Roy. 2007. "Identifying \& correcting non-science student preconceptions through an inquiry-based, critical approach to evolution." American Biology Teacher 69 (8): $460-466$. 
Rosenblith, S., and B. Bindewald. 2014. "Between mere tolerance and robust respect: mutuality as a basis for civic education in pluralist democracies." Educational Theory 64: 589-606.

Scott, M. 2007. Rethinking Evolution in the Museum. Abingdon: Routledge.

Selkirk, D. R., and F. J. Burows, eds. 1987. Confronting Creationism: Defending Darwin. Kensington, NSW: New South Wales University Press.

Smith, M. U., and H. Siegel. 2004. "Knowing, believing, and understanding: what goals for science education?" Science \& Education 13: 553-582.

Stradling, R. 1984. "Controversial issues in the classroom.” In Teaching Controversial Issues, edited by R. Stradling, M. Noctor, and B. Baines, eds. 1-12. London: Edward Arnold.

Tracy, J. L., J. Hart, and J. P. Martens. 2011. "Death and science: The existential underpinnings of belief in intelligent design and discomfort with evolution." PLoS ONE, 6(3): e17349. doi:10.1371/journal.pone.0017349.

Trollinger, S. L., and W. V. Trollinger. 2016. Righting America at the Creation Museum. Baltimore: Johns Hopkins Press.

Warren, M. E. 2006. "What should and should not be said: Deliberating sensitive issues." Journal of Social Philosophy 37 (2): 163-181.

Wellington, J., ed. 1986. Controversial Issues in the Curriculum. Oxford: Basil Blackwell.

White. J. 2011. Exploring Well-being in Schools: A Guide to Making Children's Lives More Fulfilling. Routledge: London.

Williams, J. D. 2008. “Creationist teaching in school science: A UK perspective.” Evolution: Education and Outreach 1: 87-95.

Winslow, M. W., J. R. Staver, and L. C. Scharmann. 2011. "Evolution and personal religious belief: Christian university biology-related majors' search for reconciliation." Journal of Research in Science Teaching 48: 1026-1049. 